\title{
CASE NOTE: JONES $v$ THE UNITED KINGDOM: ARTICLE 6(1) ECHR AND THE IMMUNITIES OF STATES AND THEIR OFFICIALS FOR ACTS OF TORTURE
}

\author{
Paul David Mora*
}

\author{
Keywords \\ State Immunity, Public Officials, Torture, Right of Access to a Court
}

The issue brought before the Fourth Section of the European Court of Human Rights $(E C t H R)$ in Jones $v$ United Kingdom ${ }^{1}$ (Jones $v$ UK) was whether the right of access to a court guaranteed by Article 6(1) of the European Convention on Human Rights ${ }^{2}(E C H R)$ was breached by the United Kingdom when its national court granted immunity to both the Kingdom of Saudi Arabia and its public officials in civil proceedings for torture. The four applicants claimed that they had been the victims of sustained and systematic torture carried out by agents of the Saudi Arabian state at a time when they were detained in a prison for involvement in criminal activities. Proceedings were subsequently initiated before the courts of England and Wales by the applicants who were of British and Canadian nationality-and it appears that the Canadian national had become a dual British national by the time of Strasbourg's judgment. The Court of Appeal ${ }^{3}$ had held that while Saudi Arabia enjoyed immunity from civil jurisdiction in proceedings involving allegations of torture, it was unable to successfully plead immunity ratione materiae on behalf of its named officials involved in the same proceedings. The House of Lords ${ }^{4}$ unanimously overturned this decision on appeal and held that both the foreign state and its officials were entitled to claim immunity. The applicants thereafter brought a case before Strasbourg challenging this decision.

Strasbourg dealt with the issue of whether ECHR Article 6(1) was engaged in a largely unsatisfactory manner. Doubt had been expressed in the House of Lords on whether Article 6(1) applied when a domestic court granted immunity

\footnotetext{
Visiting Researcher, National University of Singapore.

1 Jones \& Ors v United Kingdom [2014] ECHR 32.

24 November 1950, 213 UNTS 222 (as amended).

${ }^{3}$ Jones $v$ Ministry of the Interior Al-Mamlaka Al-Arabiya as Saudiya (The Kingdom of Saudi Arabia); Mitchell and Others $v$ Al-Dani and Others [2004] EWCA Civ 1394.

${ }^{4}$ Jones $v$ Ministry of the Interior Al-Mamlaka Al-Arabiya as Saudiya (The Kingdom of Saudi Arabia); Mitchell and Others $v$ Al-Dali and Others [2006] UKHL 26 (Jones $v$ Saudi Arabia).
}

Copyright $\odot$ the Author(s).

This work is licensed under a Creative Commons Attribution-NonCommercial-NoDerivs 3.0 License. 
in accordance with international law. Nonetheless, their Lordships proceeded on the assumption that it was given that was the position taken by the Grand Chamber in its earlier decision in Al-Adsani v United Kingdom ${ }^{5}$ (Al-Adsani v $U K)$, and that it made no difference to the overall outcome of the case. The UK government invited Strasbourg to reconsider its finding in Al-Adsani v UK, submitting that a state could not be considered to have denied access to a court in a situation where it would be contrary to international law for the court to hear the claim. More specifically, it stated that ECHR Article 6(1) 'could not require a State to arrogate to itself powers of adjudication which, under international law, it did not possess. As a consequence, a State could not be considered to have denied access to a court where it had no access to give. ${ }^{6}$ This argument was not addressed by Strasbourg which simply endorsed the finding made in Al-Adsani $v$ $U K$ that Article 6(1) was applicable in claims for damages brought against a State. While this may not be unsurprising, the position taken is unsatisfactory since the Grand Chamber in Al-Adsani v UK did not deal with this argument itself and a confused principle of ECHR jurisprudence appears to have been established which presumes that a domestic court has jurisdictional competence to adjudicate disputes involving foreign states (and their officials) when the finding is made that ECHR Article 6(1) is engaged. Such a presumption is erroneous and the better approach to determine whether Article 6(1) applies is to consider whether international law requires a national court to grant immunity in the given factual circumstances to bar its adjudicative jurisdiction over the alleged dispute.

The allocation of immunity was identified by the Chamber in Jones $v$ UK as pursuing the legitimate aim of complying with international law to promote comity and good relations between States. On the issue of whether a grant of immunity was proportionate, it had been recognised in Al-Adsani $v$ UK that 'measures taken by a High Contracting Party which reflect generally recognised rules of public international law on State immunity cannot in principle be regarded as imposing a disproportionate restriction on the right of access to a court. 7 The applicants submitted in Jones $v U K$ that employing this variation of the proportionality test was wrong for two reasons. First, it was alleged that the allocation of immunity completely bars any judicial determination of the dispute brought before the domestic court and does not allow for the competing interests at stake to be structurally balanced against each other. Support for this argument

\footnotetext{
${ }^{5}$ Al-Adsani v United Kingdom [2002] 34 EHRR 11.

${ }^{6}$ Jones $v$ UK, above $\mathrm{n} 1$, para 162.

7 Al-Adsani v UK, above n 5, para 56.
} 
(although not cited in this case) could be found in the Dissenting Opinion of Judge Loucaides in Al-Adsani $v U K$, who stated that 'courts should be in a position to weigh the competing interests in favour of upholding an immunity or allowing a judicial determination of a civil right, after looking into the subject matter of the proceedings. 8 In addition, it was argued, secondly, that this variation of the proportionality test failed to consider whether there existed an alternative means of redress allowing the applicants to pursue their civil claim, and that the balancing exercise was the appropriate test in which due consideration was to be given to this issue. Reference was made to the decision in Waite and Kennedy $v$ Germany where Strasbourg had held that a 'material factor' in determining the proportionality of an interference in a case involving the immunity of an international organisation was whether the applicants had available to them reasonable alternative means to effectively protect their rights. ${ }^{9}$ In this regard, the applicants in Jones $v U K$ claimed that they did not enjoy an alternative means of redress as the courts in Saudi Arabia were neither independent nor impartial, and they were unable to return to the place where they had been tortured in order to bring their claim.

The Chamber in Jones $v U K$ declined to depart from the variation of the proportionality test used in Al-Adsani $v U K$ because of the need 'to interpret the Convention so far as possible in harmony with other rules of international law of which it forms part.' ${ }^{10}$ This was an important finding (although one that has been made on previous occasions). In a similar vein to the comments already advanced above, the ECHR cannot create exceptions to the rules of state immunity that are not recognised by international law. State immunity is a doctrine of international law which gives effect to the horizontal nature of the legal system and the equality of independent sovereigns. The International Court of Justice (ICJ) in the Jurisdictional Immunities of the State case made clear that the principle of sovereign equality from which immunity derives is one of the fundamental principles of the international legal order. ${ }^{11}$ States therefore enjoy a general right under international law not to be involved in judicial proceedings before the courts of another State without their consent. This general rule is subject, however, to clearly defined exceptions that are firmly established and widely accepted by states in either customary international law or a treaty. On

\footnotetext{
${ }^{8}$ Al-Adsani $v$ UK, above $\mathrm{n} 5$ (Judge Loucaides, diss).

9 Waite and Kennedy $v$ Germany [2000] 30 EHRR 261, para 68.

${ }^{10}$ Jones $v U K$, above $\mathrm{n} 1$, para 195.

${ }^{11}$ Jurisdictional Immunities of the State (Germany v Italy; Greece intervening), ICJ, Judgment of 3 February 2012, para 57 (Jurisdictional Immunities).
} 
this basis, Strasbourg could only employ a test of proportionality which led to any potential finding that it reached under the Convention being compatible with international law, which, at one and the same time, placed separate and additional obligations on the respondent state. Its decision to use a variation of the test which broadly considered whether the interference to ECHR Article 6(1) was rationally connected to the legitimate aim of complying with the international rules of state immunity, instead of one that balanced the competing interest, was therefore correct.

When arriving at its conclusion to follow the proportionality test laid down in Al-Adsani $v U K$, the Chamber in Jones $v U K$ did not engage with either of the arguments raised by the applicants advocating for a variation of the test which provided for a substantive assessment. In any event, these arguments are unconvincing and should have been rejected by Strasbourg. The first argument which claimed that it was wrong for the House of Lords to not have balanced the competing interests against each other misunderstands how domestic courts determine whether to grant immunity when it is pleaded. The matter is well explained by Lord Bingham in the underlying case when identifying that: '[w] here applicable, state immunity is an absolute preliminary bar, precluding any examination of the merits. A state is either immune from the jurisdiction of a foreign court or it is not. There is no [...] scope for the exercise of discretion'. ${ }^{12}$ In relation to the second argument claiming that the proportionality test should consider whether there existed an alternative remedy, the ICJ confirmed in the Jurisdictional Immunities of the State case that any entitlement to immunity under international law is not 'dependent upon the existence of [an] effective alternative means of securing redress.' ${ }^{13}$ It was somewhat surprising that reference was not made to this particular finding of the ICJ given that Strasbourg had cited it with approval in Stichting Mothers of Srebrenica $v$ Netherlands, where it had specifically held that it does not follow [...] that in the absence of an alternative remedy the recognition of immunity is ipso facto constitutive of a violation of the right of access to a court.' ${ }^{\prime 4}$ In reconciling this decision with Waite and Kennedy v Germany, it was further held in Stichting Mothers of Srebrenica $v$ Netherlands that the lack of an alternative means of redress was only a 'material factor' and one that could not be interpreted in absolute terms.

Having determined which variation of the proportionality test to employ,

\footnotetext{
${ }^{12}$ Jones $v$ Saudi Arabia, above n 4, para 33.

${ }^{13}$ Jurisdictional Immunities, above $\mathrm{n} 11$, para 101.

14 Stichting Mothers of Srebrenica v The Netherlands [2013] 57 EHRR SE10, para 164.
} 
the first question that Strasbourg considered under this test was whether the decision of the House of Lords to grant immunity to Saudi Arabia in civil proceedings for torture was in accordance with the international rules of State immunity. As is well known, the Grand Chamber in Al-Adsani $v U K$ had been split by a very narrow majority over this question with the Joint Dissenting Opinion taking the view that the violation of a peremptory norm of jus cogens 'deprives the rule of sovereign immunity of all its legal effects.' ${ }^{15}$ The inherent difficulty with this argument, as acknowledged by the majority, is that jus cogens are norms of customary international law, and at the time that Al-Adsani $v$ $U K$ was decided there was no widespread and consistent practice supporting this consequential effect ensuing from their violation. Rather than examine international practice to determine whether custom had evolved since this decision was handed down in 2001, the Chamber in Jones $v$ UK referred with deference and approval to the judgment of the ICJ in the Jurisdictional Immunities case which had recently considered this matter in detail and similarly held that there was nothing inherent in the concept of jus cogens displacing the rules of state immunity. ${ }^{16}$ Customary international law was found to have only bestowed the substantive prohibition with a peremptory status, and this did not conflict with the rules of state immunity which are procedural in nature. It is also worth noting that the ICJ further held that custom did not recognise an exception to the jurisdictional immunities enjoyed by a state in cases involving serious violations of human rights committed outside the territory of the forum state. ${ }^{17}$ Accordingly, Strasbourg was right in finding that the House of Lords' decision to uphold the immunity of a foreign state in civil proceedings for torture did not amount to a disproportionate interference to ECHR Article 6(1).

Al-Adsani $v U K$ had been concerned with the immunity from jurisdiction enjoyed by a State under international law. The second question Strasbourg considered under the test of proportionality (and the one which the case will receive attention for) was whether the decision to allow the Kingdom of Saudi Arabia to successfully plead immunity ratione materiae on behalf of its officials for acts of torture reflected generally recognised rules of international law. Strasbourg approached this issue by making the initial finding that in principle [...] officers of a foreign State [enjoy] protection in respect of acts undertaken on behalf of the State under the same cloak as protects the State itself.' ${ }^{18}$ This

\footnotetext{
${ }^{15}$ Al-Adsani v UK, above n 5, para 4 (Joint Diss Op).

${ }^{16}$ Jurisdictional Immunities, above n 11, para 95.

17 Ibid, para 91.

${ }^{18}$ Jones $v$ UK, above $\mathrm{n} 1$, para 204.
} 
finding recognises that international law regards actions brought against State officials for acts performed in an official capacity to be, in effect, actions brought against the State. This is because an act cannot be carried out by a State itself and may only be performed by an individual acting on its behalf. Article 2(1)(b)(iv) of the UN Convention on Jurisdictional Immunities of States and their Property, ${ }^{19}$ which codifies international practice on this point, reflects this by providing that the term 'State' means 'representatives of the State acting in that capacity'. Whilst Strasbourg's finding is correct an important caveat to note is that, strictly speaking, immunity ratione materiae is a subject matter immunity that attaches to the official act and not to the individual public official. The plea of immunity before the domestic court is invoked by the foreign state on behalf of its representative implicated in the proceedings because it is the state, and not the official, who enjoys the immunity. On this basis, any denial of immunity ratione materiae in respect of acts attributable to the state would in practice circumvent the other and separate immunities enjoyed by the state under international law. Having identified that immunity ratione materiae will only be granted in respect of official acts, consideration then turned to determine whether acts of torture are committed in an official or private capacity. Although Strasbourg did not offer a firm view on this matter it is clear that, according to Article 1 of the UN Convention against Torture ${ }^{20}(C A T)$, torture is by definition an act 'inflicted by [...] a public official or other person acting in an official capacity'. Moreover, and with respect to the underlying facts of this particular case, the alleged acts of torture had taken place in state-owned premises and had been committed by public officials as part of their duties to interrogate the applicants for involvement in serious criminal activities.

The Chamber identified that there was 'some emerging support in favour of a special rule or exception in public international law in cases concerning civil claims for torture lodged against foreign State officials. ${ }^{21}$ State practice was found to be 'in a state of flux' and '[i]nternational opinion on the question may be said to be beginning to evolve.' ${ }^{22}$ This is perhaps an overstatement. The practice offering an exception to immunity ratione materiae in civil proceeding for torture (rather than criminal proceeding for torture) is largely to be found in certain cases decided in the United States. As recently demonstrated by the US

\footnotetext{
${ }^{19}$ UN Doc A/59/508 (2 December 2004).

${ }^{20} 10$ December 1984, 1465 UNTS 85.

21 Ibid, para 213.

22 Ibid.
} 
Court of Appeals for the Fourth Circuit in Yousuf $v$ Samantar, ${ }^{23}$ these decisions take the position that although the acts may well be committed in the course of an official's employment, their heinous nature both exceeds that which might be considered to be within the lawful scope of the official's authority and cannot properly be characterised as an official act of the sovereign state. The United States' practice is not uniform and any weight attributed to these cases needs to be balanced against conflicting judicial decisions ${ }^{24}$ as well as statements made by the Government. ${ }^{25}$ In any event, Strasbourg was nonetheless correct in observing that the "bulk of the authority ${ }^{26}$ is to the effect that immunity ratione materiae is to be granted in civil proceedings for torture as evidenced by cases decided in Australia, ${ }^{27}$ Canada $^{28}$ and New Zealand. ${ }^{29}$ The better understanding of the state practice is that there are a few instances of judicial decisions of limited weight supporting such an exception to state immunity, rather than a trend beginning to evolve and emerge. It is also worth mentioning that this limited practice is premised on false reasoning. In the Jurisdictional Immunities case the ICJ held that, notwithstanding their unlawfulness, serious violations of the law of armed conflict were sovereign acts under the law of state immunity. ${ }^{30}$

As a final argument, the applicants submitted that any grant of immunity ratione materiae in civil proceedings for torture had been abrogated by the CAT (which both the United Kingdom and Saudi Arabia were parties to). It was contended that CAT Article 14(1) established a framework of universal civil jurisdiction that required contracting parties to provide an enforceable right to compensation in their domestic legal systems for acts of torture that had been committed extra-territorially and had no nexus with the forum state. Following the reasoning of the House of Lords in $R v$ Bow Street Metropolitan Stipendiary Magistrate; ex parte Pinochet Ugarte (No 3), ${ }^{31}$ it was further submitted that immunity ratione materiae could not co-exist with universal jurisdiction over torture and, therefore, had been set aside by Article 14(1). This argument was not explored in any detail by Strasbourg which, rather dismissively, simply observed that

\footnotetext{
${ }^{23}$ Yousuf $v$ Samantar, 699 F.3d 763 (2012).

${ }^{24}$ See e.g. Matar v Dichter, 563 F.3d 9 (2d Cir, 2009).

${ }^{25}$ See e.g. Brief for the United States of America as Amicus Curiae in Support of Affirmance, Matar $v$ Dichter, No 07-2579-cv (19 December 2007).

${ }^{26}$ Jones $v$ UK, above $\mathrm{n} 1$, para 213.

${ }^{27}$ Zhang $v$ Zemin [2010] NSWCA 255.

${ }^{28}$ Islamic Republic of Iran $v$ Hashemi [2012] QCCA 1449.

${ }^{29}$ Fang $v$ Jiang [2007] NZAR 420.

${ }^{30}$ Jurisdictional Immunities, above n 11, para 60.

31 [2000] 1 AC 147.
} 
the 'question whether the Torture Convention has given rise to universal civil jurisdiction is [...] far from settled, ${ }^{32}$ Nonetheless, the proper reading of CAT Article 14(1) is that it does not establish universal civil jurisdiction. Although the provision is silent with regard to its territorial application, state practice (as demonstrated by the submission made by the United Kingdom to the ECtHR in Jones $v(U K)$ has interpreted the right enforceable before a national court to only cover the harm occurring in the territorial jurisdiction of the contracting party.

Strasbourg concluded that the House of Lords' decision to allow Saudi Arabia to plead immunity ratione materiae on behalf its officials in civil proceedings for torture reflected generally recognised rules of international law, and was therefore not a disproportionate interference to ECHR Article 6(1). Although the judgment in Jones $v U K$ lacked detail in places by not fully engaging with some of the arguments raised, the overall conclusions drawn were both correct and unsurprising. The decision will of course be disappointing to the applicants who have sought redress for the violation of their fundamental rights over many years. It is important to recall that while international law may bar the domestic courts of a state from adjudicating a claim involving a foreign state, it does not absolve the responsibility of that foreign state from providing a remedy in an appropriate forum. One can only sympathise with the position that individuals find themselves in when they are denied a remedy by the responsible state and are unable to have access to the domestic courts of another state by the law.

${ }^{32}$ Jones $v$ UK, above n 1, para 208. 